\title{
Therapeutic Effect of L-Carnitine on Acute Pancreatitis Induced by L-Arginine in Rats: Possible Role of Beclin Gene and Inducible Nitric Oxide Synthase
}

\author{
GHADA F. SOLIMAN, M.D.*; WALAA IBRAHIM, M.D.** and HANAN ABDALLAH, M.D.*** \\ The Departments of Medical Pharmacology*, Medical Biochemistry \& Molecular Biology** and Medical Histology**, \\ Faculty of Medicine, Cairo University, Egypt
}

\begin{abstract}
Background: Acute Pancreatitis (AP) is characterized by a severe inflammation, associated with premature activation of pancreatic digestive enzymes, cytoplasmic vacuolization, and infiltration of inflammatory cells into the pancreas. Medical therapy remains the principal option for treating AP. However, there is no specific effective drug to treat it.

Aim of Study: This study is an experimental study that evaluates the therapeutic effect of L-carnitine at different doses on 1-arginine induced pancreatitis in rats.

Material and Methods: Thirty healthy adult male albino rats were involved in this study. AP was induced by L-arginine at a dose of $(200 \mathrm{mg} / 100 \mathrm{~g}$ intraperitoneal twice at an interval of $1 \mathrm{~h})$. L carnitine $(100,300,500 \mathrm{mg} / \mathrm{kg})$ was injected daily intraperitoneally for one week in treatment of acute pancreatitis in rats. The pancreatic injury was assessed using pharmacological, biochemical and histological approaches. We evaluate the systolic blood pressure before and after treatment and pancreas to body weight ratio. Biochemical measurement of serum amylase, pancreatic tissue glutathione and malondaldehyde, gene expression of Beclin by real time PCR. Also, all groups were examined histopathologically.

Results: Our work revealed that L-arginine injected group showed significant acute pancreatitis biochemically and histopathologically in addition to increased percentage change of systolic blood pressure. While those treated by L-carnitine especially $(500 \mathrm{mg} / \mathrm{kg})$ showed significant improvement biochemically as shown by increased pancreatic tissue glutathione level and decreased pancreatic tissue malondialdehyde level, also decreased gene expression of Beclin that approaches to normal, and histopathologically mainly in area of iNOS which is decreased towards normal.

Conclusion: It is concluded that dose related L-carnitine can have a role of acute pancreatitis treatment not only by its antioxidant effect but also by being inhibitor of nitric oxide synthase and by affection of autophagy which is represented by Beclin gene expression.
\end{abstract}

Key Words: Acute pancreatitis - L-carnitine - L-arginine Beclin-iNOS.

Correspondence to: Dr. Walaa Ibrahim, E-Mail: walaaibrahim@kasralainy.edu.eg

\section{Introduction}

ACUTE Pancreatitis (AP) is a disease that varies and ranges from a mild and localized self-limiting disease to widespread and fatal multi-organ failure that may lead to death. Mild pancreatitis includes inflammation and edema but with the addition of necrosis and secondary injury to organs other than pancreas is considered to be severe pancreatitis $[1,2]$. No pharmacologic therapy is currently available to limit the disease and its progression inspite of its increased incidence [3]. Pancreatitis treatment is mainly supportive with the addition of organ supportive measures and antibiotics when organ failure [4] or infected necrotic pancreatitis occur [5] respectively.

Pancreatic edema and necrotic process of AP occur due to apoptosis by the participation of Oxygen Free Radical (OFR) in acinar cells [6] Also, OFR are involved in pain which represents an important clinical symptom of AP [7] that directly attacks biological membranes mainly lipids and proteins disrupting their functions by lipid oxidation and protein modification of the pancreatic cell membrane, depolarizing the mitochondrial membrane, and inducing fragmentation of DNA [8] Inflammatory response in AP is represented mainly by circulating cytokines or chemokines that produce their effects through receptors on cell surface. They interpose the inflammatory process by stimulation

\footnotetext{
Abbreviations:

AP : Acute Pancreatitis.

LC : L-Carnitine.

SBP : Systolic Blood Pressure.

MDA : Malondialdehyde.

GSH : Reduced Glutathione.

ROS : Reactive Oxygen Species.
} 
of enzymes as inducible Nitric Oxide Synthase (iNOS) and cyclooxygenase- 2 so by their inhibition local and systemic injury induced by the main proinflammatory leukocytes are limited [9]. Pathogenesis of acute pancreatitis involve both Reactive Nitrogen Species (RNS) and Reactive Oxygen Species (ROS) by two-fold through acting on biomolecules including lipids, proteins, and nucleic acids directly leading to their oxidation in cell membrane producing pancreatic cells disintegration and necrosis. In addition to their role as secondary messengers in intracellular signaling initiating proinflammatory cascades [10].

Also, acute phase of pancreatitis strongly changes gene expression which could either help the pancreas by self-protection from an acute attack or on the opposite, take part in the mechanism of the disease. Therefore, new strategies in the treatment of the disease could de discovered by identifying the genes involved in cell response [11]. The mechanism by which arginine causes pancreatitis is not exactly known. There are many suggested mechanisms that oxygen free radicals [12], nitric oxide [13], inflammatory mediators [14] all have an essential role in the development of such disease. Autophagy is an essential process for normal cell homeostasis. It is being considered as one of the cellular defense against increased oxidative stress as well as other diverse cell stress conditions [15] Autophagy has been reported to regulate oxidative stress and inflammation signaling and formation [16]. Dysregulated autophagy might promote the inflammatory response in the pancreas [17].

L-Carnitine (LC) is an amino acid-like molecule that plays an active role in transporting fatty acids and producing Acetyl $\mathrm{CoA}$ in mitochondrial matrix for 3 -oxidation to provide energy which is needed for metabolism. It has better effects on cell injury studied in many researches [18]. As an antioxidant, acetyl l-carnitine most probably protects tissues from oxidative stress by stabilizing cell membranes, leaving them more resistant to free radicals, may be by enhancing the repair of the phospholipid bilayer destroyed by oxidant stress, rather than as a direct scavenger of free radicals or decreasing their generation [19].

From the previous information, this study has been attempted to identify the main mechanisms by which L-arginine-induced AP, declare the role of L-carnitine at different doses as an inhibitor of inducible nitric oxide synthase, also on Beclin reduction as a marker of autophagy in addition to identify the correlation between antioxidants to Beclin and iNOS.

\section{Material and Methods}

\section{Animals:}

Thirty healthy adult male albino rats (Rattus rattus) weighing 200-220gm were involved in this study. Rats were bred in the Animal House at Kasr El-Aini, Faculty of Medicine, Cairo University from April 2017 - April 2018, and divided into 5 groups. Each group of rats was housed in a cage at ordinary room temperature, humidity, natural daily light dark cycle, and fed with the standard diet which is rodents' pellets and clean water. The rats were left for an initial adaptation period for at least one week before subjecting them to the experimental manipulation(s). All the experiments were done between 09.00a.m. and 04.00p.m. and were conducted according to the regulations of the Institutional Animal Care and Use (IACUC) Cairo University.

\section{Drugs:}

A- L-carnitine (Arab Co. For Pharm. and Medicinal Plants (MEPACO), Cairo, Egypt): It was provided as ampoules injected intraperitoneal daily in a single injection of different doses $(100$, $300,500) \mathrm{mg} / \mathrm{kg}$.

B- L-arginine powder (A Johnson Matthey Company, Kartshruhe, Germany): It was prepared as a solution by dissolving in $0.9 \%$ saline to a final concentration of $100 \mathrm{mg} / \mathrm{ml}$.

\section{Experimental design:}

The rats were divided into 5 groups (6 rats each) and subjected to the study for one week after injection of arginine: The first and the second groups (negative and positive control group respectively): Provided with normal saline and L-arginine at a dose of $(200 \mathrm{mg} / 100 \mathrm{~g}$ intraperitoneal twice at an interval of $1 \mathrm{~h}$ ) were used respectively [20]. The other three groups were given l-arginine and then treated after injection as follows: The third, fourth, fifth groups were treated with L-carnitine at different doses $(100 \mathrm{mg} / \mathrm{kg}$ [21], 300mg/kg [22], $500 \mathrm{mg} / \mathrm{kg}$ [23] injected once daily intraperitoneally for one week.

\section{Estimation of pancreatitis pharmacologically:}

1- Blood pressure measurement: Systolic Blood Pressure (SBP) of each rat was measured before and after pancreatitis induction. It was determined using non-invasive blood pressure methodology in conscious rats [24]. Exposure to arginine tends to elevate SBP after the tests, so difference between measurements before and after the tests was recorded [25] for each rat, SBP values were calculated as the mean of a 
minimum of three measurements. Then $\%$ change in blood pressure was calculated as follows: $\%$ change of blood pressure $=($ Systolic blood pressure after tests in $\mathrm{mmHg}$ - Systolic blood pressure before tests in $\mathrm{mmHg}$ )/Systolic blood pressure before tests in mmHg X 100.

2- Pancreas to body weight ratio: The pancreas was removed immediately after scarification, trimmed of fat and weighed. The pancreatic weight/body weight ratio $(\mathrm{mg} / \mathrm{g})$ was calculated for each animal to estimate the level of pancreatic edema [26].

\section{Biochemical estimation:}

1-Estimation of serum amylase: Amylase activity was estimated in serum, using a commercially available kit according to the manufacturers' protocols.

2- Measurement of reduced glutathione (GSH): It depends on the reduction of 5, 5 dithiobis (2nitrobenzoic acid) (DTNB) with reduced glutathione (GSH) producing a yellow compound. The reduced chromogen is directly proportional to GSH concentration so its absorbance was measured at $405 \mathrm{~nm}$ by using its kit [27] .

3-Measurement of Malondialdehyde (MDA): To measure its concentration, $100 \mathrm{mg}$ of the pancreatic tissue was homogenized in $1 \mathrm{~mL}$ PBS, $\mathrm{pH}$ 7.0 with micro pestle. $20 \%$ Trichloroacetic Acid (TCA) was added to pancreatic homogenate precipitating the protein, and then centrifuged. Thiobarbituric Acid (TBA) solution was added to the supernatants after their collection, then was boiled for 10 minutes in water bath, then the absorbance was measured. Concentration of MDA in supernatants of pancreatic homogenate was calculated using the standard curve [28].

4- Quantitative analysis of gene expression of Beclin by real time PCR.

RNeasy purification reagent (Qiagen, Valencia, CA) was used to extract from the pancreatic tissue homogenate according to manufacturer's instruction. The RNA concentrations and purity were measured with an ultraviolet spectrophotometer.

cDNA was generated from $5 \mu \mathrm{g}$ of total RNA extracted with 1 (20) pmol) antisense primer and 0.8 Lstorscript AMV reverse transcriptase for $60 \mathrm{~min}$ at $37^{\circ} \mathrm{C}$. Real-time qPCR amplification and analysis were performed using an Applied Biosystem with software version 3.1 (StepOneTM, USA). Reaction contained SYBR Green Master Mix (Applied Biosystems), gene-specific primer pairs which were shown in (Table 1), cDNA and nuclease-free water. With cycling conditions $\left(10 \mathrm{~min}\right.$ at $95^{\circ} \mathrm{C}$ followed by 40 cycles of $15 \mathrm{~s}$ at $95^{\circ} \mathrm{C}$ and $60 \mathrm{~s}$ at $\left.60^{\circ} \mathrm{C}\right)$.

Data were analyzed with the ABI Prism sequence detection system software and quantified using the v1.7 Sequence Detection Software from PE Biosystems (Foster City, CA). Comparative threshold cycle method was used to calculate relative expression of studied gene. All values were normalized to the GAPDH being the control housekeeping gene.

Table (1): Primer sequence of the studied genes.

\begin{tabular}{lll}
\hline Beclin & Forward primer: 5'-AACCCCATGCTGTCCTTTCC-3' & NM: 053739.2 \\
& Reverse primer: 5'-CAACTGTGTGCCACAAGCATC-3' & \\
GAPDH & Forward primer: 5'-GATGCTGGTGCTGAGTATGTCG-3' & XR: 598347.1 \\
& Reverse primer: 5'-GTGGTGCAGGATGCATTGCTGA-3' & \\
\hline
\end{tabular}

\section{Histological examination:}

1- Specimens taken and sectioning: After scarification, the pancreas was immediately dissected out, fixed in $10 \%$ formal saline for 24 hours at room temperature, dehydrated in ascending grades of alcohol $(70 \%, 95 \%, 100 \%)$, cleared in xylene then embedded into paraffin wax (Department of Histology, Faculty of Medicine, Cairo University). Sections of $5 \mu \mathrm{m}$ thickness were subjected to:

A- Hematoxylin \& eosin (H \& E) [29].
B- Immunohistochemical staining for iNOS:

The staining was done according to Bancroft and Cook using a mouse monoclonal antibody (Novocastra Lyphilized Corporation laboratories, UK, catalogue number GTX3 1048) [30]. Deparaffinization of paraffin sections were done in xylene for 1 2 minutes and then rehydrated in descending grades of ethanol then were put into distilled water for 5 minutes. Hydrogen peroxide was used to incubate sections for 30 minutes then rinsed in PBS ( 3 times, 2 minutes each). Then each section was incubated with 2 drops (=100 athe primary 
antibody CD34 Ab-1, Clone QBEnd/10 (Lab Vision Corporation Laboratories, CA 94539, USA, catalogue number MS-363-R7) for 60 minutes. Slides were rinsed well in PBS (3 times, $2 \mathrm{~min}$. each), incubated for 20 minutes with 2 drops of biotinylated secondary antibody for each section then rinsed well with PBS. Each section was incubated with 2 drops (100 enzyme conjugate "streptavidinhorseradish peroxidase" for 10 minutes at room temperature then washed in PBS. Substratechromogen (DAB) mixture 2 drops was applied to each section and incubated at room temperature for 5 10min. Then rinsed well with distilled water. Slides were counterstained with Meyer's hematoxylin, dehydrated and mounted. iNOS immunopositivity appeared as cytoplasmic brown deposits in the affected pancreatic acinar and ductal cells. All steps were performed in a humidity chamber to prevent drying of the tissues without a specific background.

\section{2- Histopathologic pancreatic damage score: Score} of pancreatic damage were calculated with a maximum of 12 by grading acinar cell degeneration, interstitial inflammation, edema, and hemorrhage. The standards were modified as follows: 1. Acinar cell degeneration: 0, absent; 1 , focal (5\%); 2 , and/or sublobular (20\%); 3 , and/or lobular (20\%). 2. Inflammation was scored as: 0 , absent; 1 , mild; 2 , moderate; 3 , severe. 3. Grading for edema was scaled as 0 , absent; 1 , edema in the interlobular space; 2 , edema in the intralobular space; 3 , edema in pancreatic acini. 4. Parenchymal hemorrhage was scored as: 0 , absent; 1 , mild; 2 , moderate; 3 , severe [31].

3- Histomorphometric study: Data were obtained using "Leica Qwin 500C" Image Analyzer Computer System Ltd. (Cambridge, England). Mean area percent of iNOS immunopositive cells were measured in all immunostained pancreas sections. From each section 10 non-overlapping fields were examined using an objective lens $\mathrm{X}$ 10 (=total magnification X100) and the mean value for each slide was obtained.

\section{Statistical methods:}

Data was coded and entered using the statistical package SPSS (Statistical Package for the Social Science) [IBM Inc., the USA] Version 21. Numeric data were examined for normality and were presented as median and quartiles. Groups were compared using the non-parametric Mann Whitney test. Spearman rank correlation was used.

A probability level of less than or equal 0.05 was considered statistically significant [32].

\section{Results}

Pharmacological results:

1- Effect of L-arginine on \% change of systolic blood pressure and pancreatic weight: $\%$ change of SBP and pancreatic weight increased significantly in L-arginine treated group compared to control group $(p<0.05)$ (Table 2), Fig. (1).

2- Effect of L-carnitine $(100,300,500 \mathrm{mg} / \mathrm{kg})$ on $\%$ change of SBP and pancreatic weight: Treating with L-carnitine $(100 \mathrm{mg} / \mathrm{kg})$ showed a nonsignificant decrease in \% change of SBP compared to the diseased group ( $p>0.05)$. L-carnitine $(300,500 \mathrm{mg} / \mathrm{kg})$ significantly decreased $\%$ change of systolic blood pressure compared to L-arginine treated group $(p<0.05)$, while pancreatic weight showed a non-significant decrease in all treated groups compared to the L-arginine treated group $(p>0.05)$ (Table 2), Fig. (1).

\section{Biochemical results:}

The serum amylase level was significantly increased in the AP group compared to the control group $(p<0.05)$, all treated groups showed significant decrease in the serum amylase level compared to diseased group with non-significant difference between all treated groups Fig. (2), L-arginine significantly increased MDA level together with decreased the pancreatic tissue GSH compared to the control group $(p<0.05)$. Treatment with Lcarnitine significantly decreases pancreatic tissue MDA together with increased pancreatic GSH compared to the diseased group $(p<0.05)$ Figs. $(3,4)$ respectively. Beclin gene expression was significantly increased in the acute pancreatitis group compared to the control group $(p<0.05)$. Treatment with L-carnitine with different doses significantly decrease the beclin gene expression compared to the pancreatitis group $(p<0.05)$ (Table 3), Fig. (5).

Correlation between serum amylase in all rats to systolic blood pressure, GSH, MDA, Beclin, and area of iNOS.

There was a significant positive correlation between the level of serum amylase and systolic blood pressure, GSH, MDA and area of iNOS, while there was a significant negative correlation between the level of serum amylase and expression of beclin gene (Table 4).

\section{Histological results:}

1- Hematoxylin and Eosin stained pancreatic sections: Control group revealed normal structure of the pancreas with different sizes and shapes of the pancreatic lobules which were formed of 
closely packed acini separated from each other by thin connective tissue septae. The acinar cells were pyramidal in shape with basal rounded vesicular nuclei and prominent nucleoli. The cytoplasm of acinar cells showed basal basophilia and apical acidophilia (Photo 1A). While Group II and Group III revealed marked disorganization of exocrine pancreas with swelling and cytoplasmic vacuolations of pancreatic acinar cells and hyperplasia of some ductal cells. Nuclei were small \& darkly stained with condensed chromatin. There was edema with inflammatory cellular infiltrate among degenerated acini (Photo 1B,C). Sections of Group IV showed moderate distortion and pyknosis of some acinar cells (Photo 1D). On other hand, Group V showed a structure nearly similar to that of the control group. However, few acinar cells appeared with vacuolated cytoplasm and pyknotic nuclei (Photo 1E).

2- Anti-iNOS stained pancreatic sections (Table 2): Sections of control group showed weak immunoreactivity (Photo 2A). While sections of Group II and Group III revealed widespread severe immunoreactivity in the form of brown cytoplasmic granules that were detected in cells of the pancreatic acini (Photo 2B,C). Group IV revealed moderate to dense cytoplasmic immunoreactivity that was detected in pancreatic acinar cells (Photo 2D). Group V revealed mild localized immune reaction (Photo 2E).

3- Histopathologic pancreatic damage score: Histopathological features of the pancreas were performed according to the standards of Schmidt pancreatitis score (Table 5).
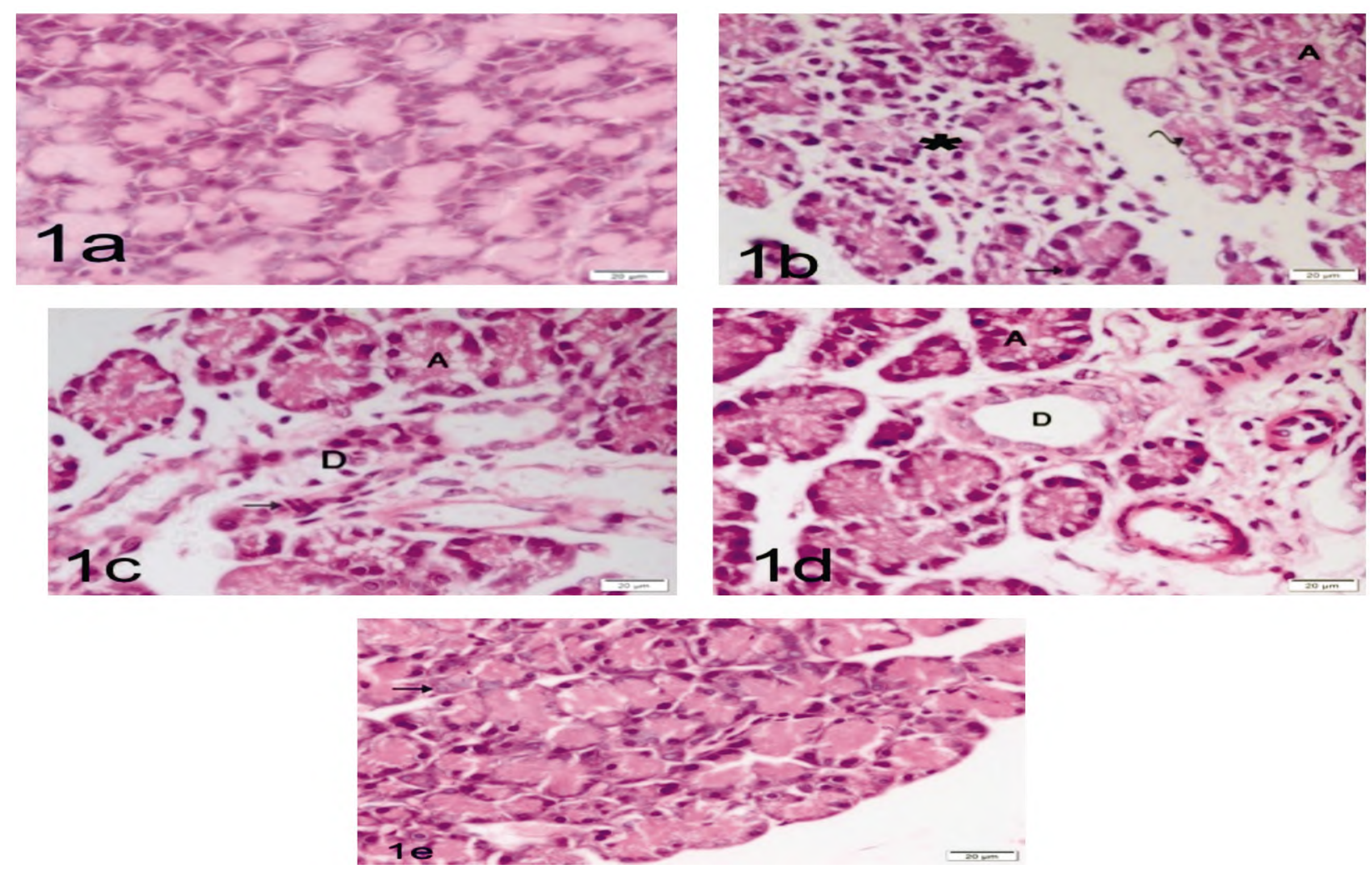

Photo (1): Photomicrographs of sections in the pancreas of rats from:

(1A): Control group showing the pancreatic acini lined with large pyramidal cells with basal rounded vesicular nuclei. Basal basophilia and apical acidophilia of acinar cells are observed.

(1B): Group II showing massive distortion of pancreatic acini. Most of the acinar cells show vacuolation (A) of their cytoplasm and pyknosis (arrows) of their nuclei. Other cells showing karyolitic changes (curved arrow). Notice edema and inflammatory infiltrate among degenerated acini (astrex).

(1C): Group III showing persistence of necrosis of acini (A) with the inflammatory exudates distortion of pancreatic duct showing hyperplasia (D) with elongated nuclei (arrow).

(1D): Group IV showing minimal inflammatory exudates between the necrotic acini (A). Note the normal duct (D).

(1E): Group V showing nearly normal pancreatic architecture with the majority of acinar cells appear with vesicular nuclei (arrow). (H \& E X400). 

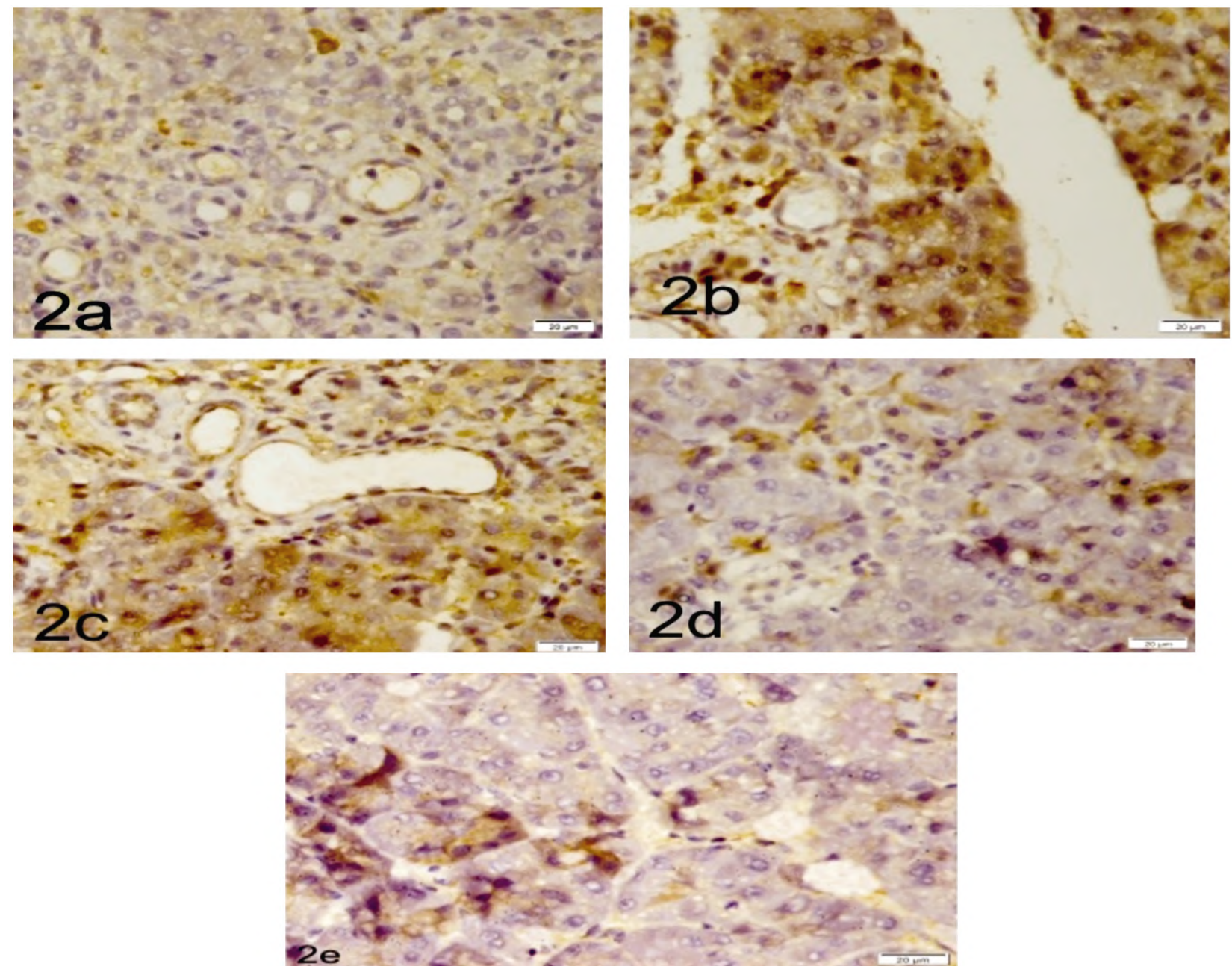

Photo (2): Photomicrographs of sections in the pancreas of rats from:

(2A): Control group showing pancreatic acini with weak immunostaining reaction (brown color) for anti-iNOS.

(2B): Group II showing intense widespread positive iNOS immunoreactivity in the pancreatic acinar and ductal cells.

(2C): Group III showing similar reaction as in Group II.

(2D): Group IV showing pancreatic acini with moderate immunostaining reaction for anti-iNOS.

(2E): Group V showing pancreatic acini with minimal and localized immunostaining reaction for anti-iNOS (Anti iNOS immunostaining X400).

Table (2): Median level (quartiles) of \% change in systolic blood pressure, pancreatic weight, area of iNOS as pharmacological and histopathological parameters of all studied groups: $\mathrm{N}=6$.

\begin{tabular}{|c|c|c|c|c|c|}
\hline Parameters & $\begin{array}{c}\text { Group I } \\
\text { (Control) }\end{array}$ & $\begin{array}{l}\text { Group II } \\
\text { (L-arginine } \\
\text { diseased) }\end{array}$ & $\begin{array}{c}\text { Group III } \\
\text { (L-carnitine } \\
\text { treated } 100 \mathrm{mg} / \mathrm{kg} \text { ) }\end{array}$ & $\begin{array}{c}\text { Group IV } \\
\text { (L-carnitine } \\
\text { treated 300mg/kg) }\end{array}$ & $\begin{array}{c}\text { Group V } \\
\text { (L-carnitine } \\
\text { treated 500mg/kg) }\end{array}$ \\
\hline $\begin{array}{l}\text { - \% change in systolic blood } \\
\text { pressure }(\mathrm{mmHg})\end{array}$ & $\begin{array}{l}5.5500 \\
(3.175-8.125)\end{array}$ & $\begin{array}{l}34.975 \\
(19.1425-40.445) \mathbf{a}\end{array}$ & $\begin{array}{l}17.95 \\
(15.685-20.950) \mathbf{a}\end{array}$ & $\begin{array}{l}13.235 \\
(11.440-14.5975)^{\mathbf{a}} \mathbf{b}\end{array}$ & $\begin{array}{l}10.175 \\
(6.995-11.875) \mathbf{b}\end{array}$ \\
\hline \multirow[t]{2}{*}{$\begin{array}{l}\text { - Pancreatic weight (gram) } \\
\text { - Area of iNOS }\end{array}$} & $\begin{array}{l}437 \\
(402-476.25)\end{array}$ & $\begin{array}{l}585 \\
(552.0-618.75) \mathbf{a}\end{array}$ & $\begin{array}{l}575.5 \\
(543.5-598.25) \mathbf{a}\end{array}$ & $\begin{array}{l}504 \\
(484.0-524.5) \mathbf{a}\end{array}$ & $\begin{array}{l}475 \\
(438.75-508.50)\end{array}$ \\
\hline & $\begin{array}{l}26.66 \\
(25.84-27.26)\end{array}$ & $\begin{array}{l}40.77 \\
(39.7175-42.1475)^{\mathbf{a}}\end{array}$ & $\begin{array}{l}39.98 \\
(39.6150-40.8825)^{\mathbf{a}}\end{array}$ & $\begin{array}{l}37.96 \\
(34.9875-38.7575)^{\mathbf{a}^{\prime} \mathbf{b}}\end{array}$ & $\begin{array}{l}30.32 \\
(29.6150-31.0725) \mathbf{a , b}\end{array}$ \\
\hline
\end{tabular}

a: Statistically significant as compared to control untreated group (Group I) $(p<0.05)$.

b: Statistically significant as compared to acute pancreatitis diseased group (Group II) $(p<0.05)$. 
Table (3): Median level (quartiles) of different biochemical parameters of all studied groups: $\mathrm{N}=6$.

\begin{tabular}{|c|c|c|c|c|c|}
\hline Parameters & $\begin{array}{l}\text { Group I } \\
\text { (Control) }\end{array}$ & $\begin{array}{l}\text { Group II } \\
\text { (L-arginine } \\
\text { diseased) }\end{array}$ & $\begin{array}{c}\text { Group III } \\
\text { (L-carnitine } \\
\text { treated } 100 \mathrm{mg} / \mathrm{kg} \text { ) }\end{array}$ & $\begin{array}{c}\text { Group IV } \\
\text { (L-carnitine } \\
\text { treated 300mg/kg) }\end{array}$ & $\begin{array}{c}\text { Group V } \\
\text { (L-carnitine } \\
\text { treated } 500 \mathrm{mg} / \mathrm{kg} \text { ) }\end{array}$ \\
\hline - Serum amylase U/L & $\begin{array}{l}166.5 \\
(156.75-174.0)\end{array}$ & $\begin{array}{l}1272.5 \\
(1155.0-1392.75) \mathbf{a}\end{array}$ & $\begin{array}{l}839 \\
(791.25-872.75)^{\mathbf{a}^{\mathbf{a}} \mathbf{b}}\end{array}$ & $\begin{array}{l}689 \\
(642.25-717.0)^{\mathbf{a}^{\mathbf{a}} \mathbf{b}}\end{array}$ & $\begin{array}{l}604 \\
(591.50-615.50)^{\mathbf{a}^{\prime} \mathbf{b}}\end{array}$ \\
\hline $\begin{array}{l}\text { - Glutathione transferase } \\
\mathrm{mg} / \mathrm{g} \text { tissue }\end{array}$ & $\begin{array}{l}54.65 \\
(52.425-55.875)\end{array}$ & $\begin{array}{l}19.53 \\
(17.907-22.25) \mathbf{a}\end{array}$ & $\begin{array}{l}38.08 \\
(37.275-39.425)^{\mathbf{a}} \mathbf{b}\end{array}$ & $\begin{array}{l}43.93 \\
(41.55-44.725)^{\mathbf{a}^{\mathbf{a}} \mathbf{b}}\end{array}$ & $\begin{array}{l}46.7 \\
(43.72-47.97)^{\mathbf{a}^{9} \mathbf{b}}\end{array}$ \\
\hline $\begin{array}{l}\text { - Malondialdehyde } \mathrm{nmol} / \mathrm{g} \\
\text { tissue }\end{array}$ & $\begin{array}{l}11.75 \\
(10.73-13.357)\end{array}$ & $\begin{array}{l}117.45 \\
(109.325-125.35) \mathbf{a}\end{array}$ & $\begin{array}{l}71.65 \\
(68.532-75.625)^{\mathbf{a}^{9} \mathbf{b}}\end{array}$ & $\begin{array}{l}66.25 \\
(64.55-68.35)^{\mathbf{a}^{9} \mathbf{b}}\end{array}$ & $\begin{array}{l}62.05 \\
(60.65-63.95)^{\mathbf{a}^{\prime} \mathbf{b}}\end{array}$ \\
\hline - Beclin & $\begin{array}{l}1 \\
(1.0-1.0)\end{array}$ & $\begin{array}{l}3.245 \\
(2.765-3.6075)^{\mathrm{a}}\end{array}$ & $\begin{array}{l}2.06 \\
(1.915-2.3675)^{\mathbf{a}^{\mathbf{a}} \mathbf{b}}\end{array}$ & $\begin{array}{l}1.745 \\
(1.6175-1.86)^{\mathbf{a}^{\prime} \mathbf{b}}\end{array}$ & $\begin{array}{l}1.49 \\
(1.4025-1.7525)^{\mathbf{a}^{\prime} \mathbf{b}}\end{array}$ \\
\hline
\end{tabular}

a: Statistically significant as compared to control untreated group (Group I) $(p<0.05)$.

b: Statistically significant as compared to acute pancreatitis diseased group (Group II) $(p<0.05)$.

Table (4): Results of correlation of amylase in all rats to systolic blood pressure, GSH, MDA, Beclin, and area of iNOS

\begin{tabular}{lc}
\hline \multicolumn{2}{c}{ area of iNOS } \\
\hline Parameters & Correlation coefficient $(r)$ \\
\hline Systolic blood pressure & $0.847^{* *}$ \\
GSH & $0.918^{* *}$ \\
MDA & $-0.936^{* *}$ \\
Beclin & $0.942^{* *}$ \\
area of iNOS & $0.920^{* *}$ \\
\hline
\end{tabular}

a: Statistically significant.

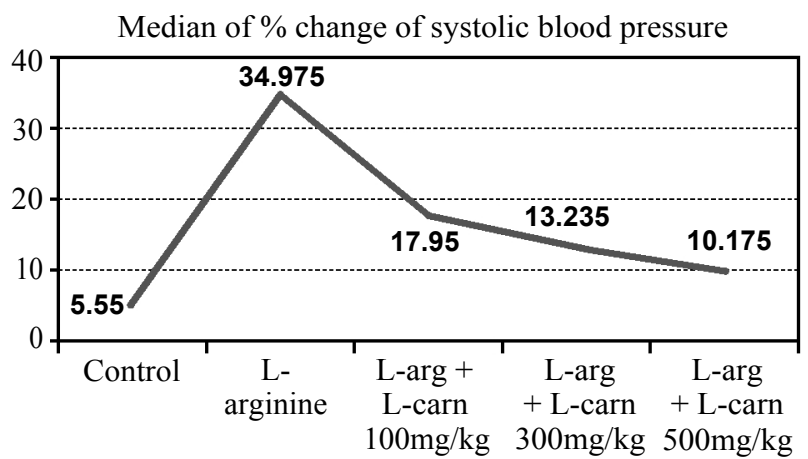

$\%$ change of blood pressure in $\mathrm{mm} / \mathrm{Hg}$

Fig. (1): Effect of different doses of L-carnitine on median of blood pressure.

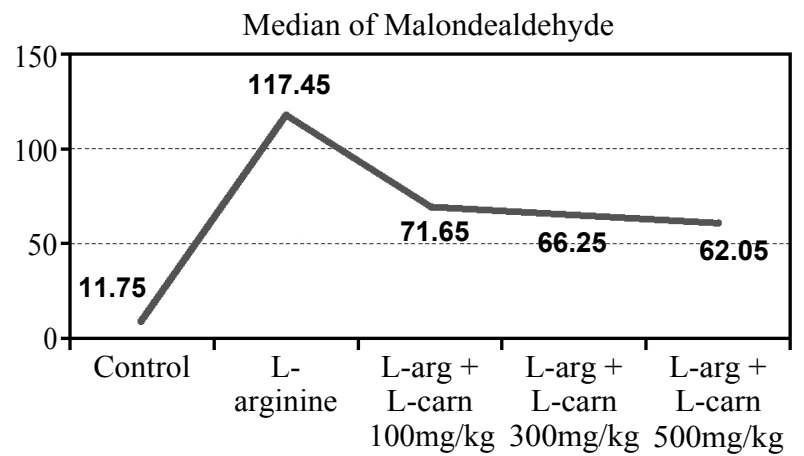

Malondealdehyde $\mathrm{nmol} / \mathrm{g}$ tissue

Fig. (3): Effect of different doses of L-carnitine on median of malondealdehyde.
Table (5): Histopathological features of the pancreas in the study groups.

\begin{tabular}{lccccc} 
& GI & GII & GIII & GIV & GV \\
\hline Necrosis of acinar cells & 0 & 3 & 3 & 2 & 1 \\
Inflammation & 0 & 3 & 3 & 2 & 0 \\
Edema & 0 & 3 & 3 & 2 & 1 \\
Hemorrhage & 0 & 2 & 0 & 0 & 0 \\
Total score $(0-12)$ & 0 & 11 & 9 & 6 & 2
\end{tabular}

Absent $=0$, mild $=1$, moderate $=2$, severe $=3$.

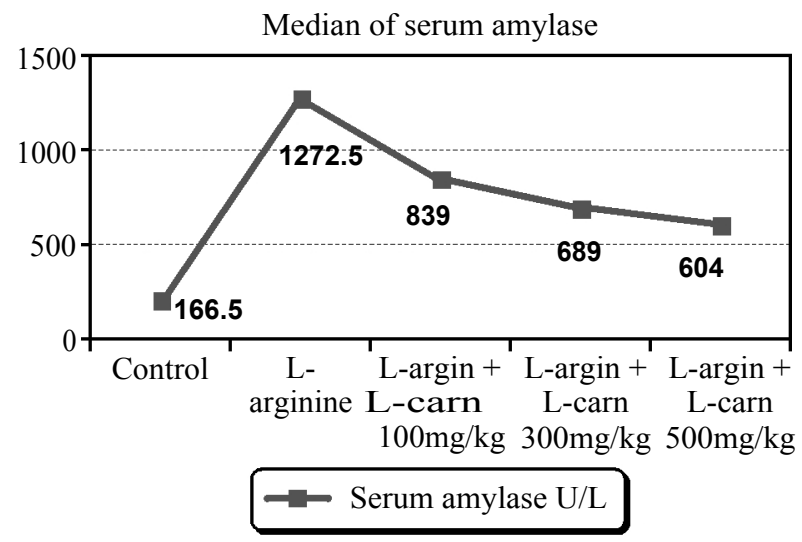

Fig. (2): Effect of different doses of L-carnitine on median of serum amylase.

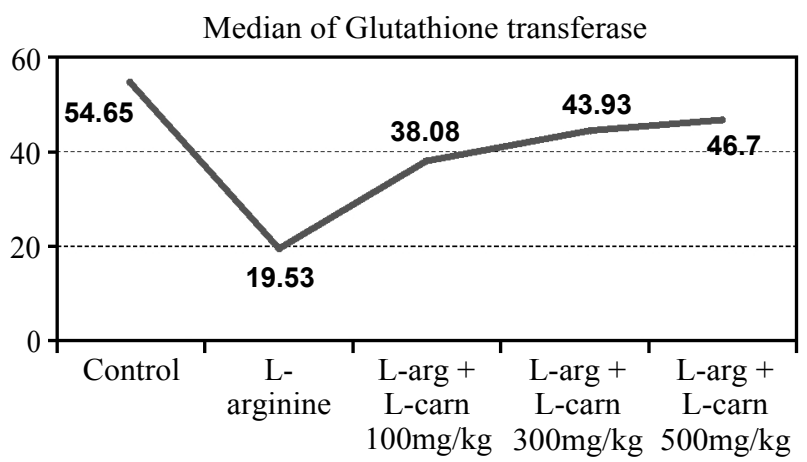

Fig. (4): Effect of different doses of L-carnitine on median of glutathione transferase. 


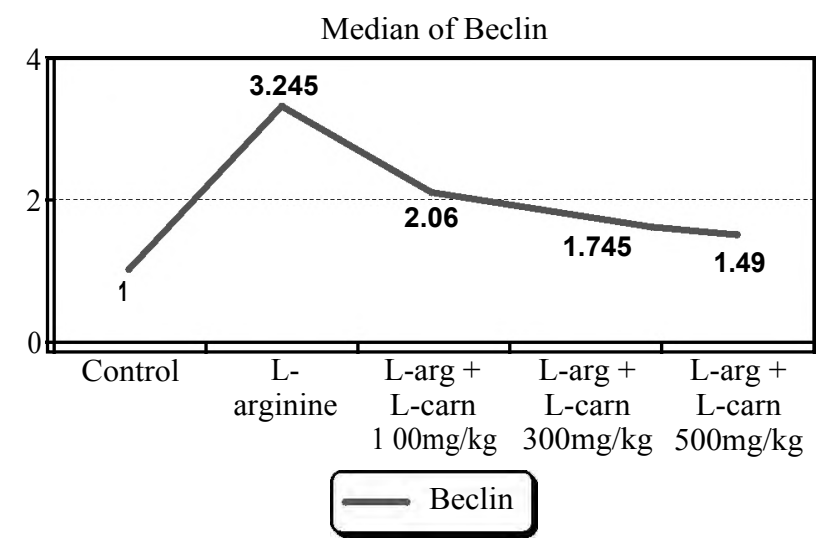

Fig. (5): Effect of different doses of L-carnitine on median of beclin.

\section{Discussion}

Acute Pancreatitis (AP) is an inflammatory disease that is characterized by being acute, reversible, and can affect several organs [33]. In the current study, L-carnitine at different doses was injected intraperitoneally to detect the mechanisms by which it could ameliorate acute pancreatitis in L-arginine treated rats as indicated by decreased activities of a-amylase in plasma and lessened edema in pancreatic parenchyma. These parameters are the primary indicators for an effective therapeutic intervention [34].

Our results revealed a significant increase of the level of serum amylase and pancreatic tissue MDA in the AP group compared to the control group, while pancreatic tissue GSH level was significantly decreased in the AP group.

Treatment with L-carnitine at different doses causes decreased level of serum amylase and pancreatic tissue MDA, while increased pancreatic tissue GSH level.

During AP, amylase is released from its acinar cells so its increased level in the serum is used for confirmation of the diagnosis [35].

In the present work L-carnitine effect on serum amylase activity may be due to its powerful antioxidant effects, Oxidative stress influenced the pathogenesis of AP [36] where the process of lipid peroxidation occurs by a chain of free radical reactions with polyunsaturated fatty acids which lead to membrane lipid breakdown into lower molecular weight fragments such as ketones, hydrocarbons, and epoxides. So, a biomarker for oxidative stress was proposed to estimate lipid peroxidation. MDA formation is the most important oxidation by-product of lipid breakdown which can represent the extent of lipid peroxidation in many organs $[37,38]$ while GSH acts as a major buffer to keep the cellular redox status in balance so it plays an important role in the antioxidant defense of the cells with a significant scavenging activity against the free oxygen radicals [39].

L-Carnitine could be a good antioxidant by its effect on free radicals (superoxide anion radical and hydrogen peroxide) by interfering with the reactive oxygen species formation and chelating the metal ferrous ions [40]. In addition to being an important cofactor of Carnitine Palmitoyltransferase 1 (CPT1), that allows the transport of fatty acid into mitochondria and their incorporation of long chain fatty acids into the $\beta$-oxidation cycle to obtain acetyl-CoA [41,42], then these substances enter the Tricarboxylic Acid (TCA) cycle to produce Adenosine Triphosphate (ATP). The synthesis of ATP consumes a large amount of oxygen, which is reduced to water at the end of the TCA cycle. So, oxygen concentration decreases which in turn decreases reactive oxygen species formation [43]

In the present work, there was a significant increase in quantitative Beclin gene expression in the acute pancreatitis group compared to the control group. Treatment with L-carnitine with different doses significantly decrease the Beclin gene expression compared to the pancreatitis group.

Autophagy dysfunction is involved in the pathogenesis of AP in addition to other human diseases [44] which is represented mainly by accumulation of large autophagic vacuoles in pancreatic acinar cells [45]. AP impairs autophagic flux which mediates formation of acinar cell vacuole, activation of trypsinogen and cell death [46]. Vacuole Membrane Protein 1 (VMP1) interacts with Beclin1, an essential regulator of autophagy and apoptosis to initiate autophagosome formation in AP which was elevated [47]. This was emphasized by the presence of Beclin 1 during induction of autophagy in the vacuoles which was colocalized with VMP 1 in its membrane in vivo. L-carnitine stabilizes cell membranes of zymogen granules against free radicals and enhances the repair of phospholipid bilayer dysfunction that resulted from free radicals' attack [48] . This was opposed by another study that indicated that expression of (VMP1) mediates "zymophagy", a selectively autophagic pathway to remove zymogen granules, and prevents the death of acinar cell of the pancreas [49]

Light microscopic examination of pancreatic sections from both Group II and Group III showed severe damage of the exocrine pancreas caused by L-arginine induced acute pancreatitis leading to 
severe necrosis of acinar and ductal cells with massive edema and cellular infiltration. Also, there was significance increase of iNOS reactivity indicating high state of injury by oxidative stress. Authors proved that l-arginine induces an increase in iNOS activity that results in high tissue levels of nitric oxide which in turn causes a direct toxic effect on the pancreas specifically its acinar cells [50]. In this work, L-carnitine therapy with higher doses such in Groups IV \& V significantly reduces the total histopathological pancreatitis' score. This may be due to its anti-inflammatory and the antioxidant effect. L-carnitine significantly reduced pancreatic iNOS activity. This may be attributed to ROS scavenging effect of L-carnitine in addition to its direct inhibitory effects on nitric oxide [51] also it may decrease the translocation of bacteria from gut into pancreas thus decreasing septic complications and mortality in acute pancreatitis [52].

\section{Conclusion:}

In our experiment, we have observed the role of Beclin and inducible nitric oxide in acute pancreatitis and the efficacy of L-carnitine with increasing doses to decrease Beclin level and inducible nitric oxide synthetase in acute pancreatitis induced by L-arginine which in turn determines the interrelation of Beclin and inducible nitric oxide with antioxidants. This may partly explain why L-carnitine could be efficient in treatment of acute pancreatitis.

Conflict of interest statement: The authors state no conflict of interest.

Research involving human participants and/or animals.

All applicable international, national, and/or institutional guidelines for the care and use of animals were followed.

\section{Acknowledgments and funding:}

This work was supported financially by the authors, and I appreciate the effort done by dr Soha El-Morsy professor at Pharmacology Department, Faculty of Medicine, Cairo University for helping in statistical results.

\section{References}

1- ESREFOGU M., GUL M. and TURAN F.: Comparative effects of several therapatic agents on hepatic damage induced by acute experimental pancreatitis. Digestive Diseases and Sciences, 53 (5): 1303-10, 2008.

2- BATCIOGLU K., GUL M., UYUMLU A.B. and ESREFOGLU M.: Liver lipid peroxidation and antioxidant capacity in cerulein-induced acute pancreatitis. Brazilian Journal of Medical and Biological Research, 42 (9): 776$82,2009$.

3- FAGENHOLZ P.J., CASTILLO C.F., HARRIS N.S., PELLETIER A.J. and CAMARGO C.A.: Increasing United States hospital admissions for acute pancreatitis, 19882003. Ann. Epidemiol., 17: 491-7, 2007.

4- Working Group IAPAPAAPG, IAP/APA evidence-based guidelines for the management of acute pancreatitis. Pancreatology, 13: e1-15, 2013.

5- BAKKER O.J., ISSA Y., VAN SANTVOORT H.C., BESSELINK M.G., SCHEPERS N.J., BRUNO M.J., BOERMEESTER M.A. and GOOSZEN H.G.: Treatment options for acute pancreatitis. Nat. Rev. Gastroenterol. Hepatol., 11: 462-9, 2014.

6- BOOTH D.M., MURPHY J.A., MUKHERJEE R., AWAIS M., NEOPTOLEMOS J.P., GERASIMENKO O.V., et al.: Reactive oxygen species induced by bile acid induce apoptosis and protect against necrosis in pancreatic acinar cells. Gastroenterology, 140 (7): 2116-25, 2011.

7- HACKERT T. and WERNER J.: Antioxidant therapy in acute pancreatitis: Experimental and clinical evidence. Antioxidants \& redox signaling, 15 (10): 2767-77, 2011.

8- INOUE S. and KAWANISHI S.: Oxidative DNA damage induced by simultaneous generation of nitric oxide and superoxide. FEBS letters, 371 (1): 86-8, 1995.

9- RARATY M.G., CONNOR S., CRIDDLE D.N., SUTTON R. and NEOPTOLEMOS J.P.: Acute pancreatitis and organ failure: Pathophysiology, natural history, and management strategies. Curr. Gastroenterol. Rep., 6: 99-103, 2004.

10- LEUNG P.S. and CHAN Y.C.: Role of oxidative stress in pancreatic inflammation. Antioxid Redox Signal., 11: $135-65,2009$

11- KEIM V., IOVANNA J.L. and DAGORN J.C.: The acute phase reaction of the exocrine pancreas. Gene expression and synthesis of pancreatitis-associated proteins. Digestion, 55: 65-72, 1994.

12- CZAKÓ L., TAKÁCS T., VARGA I.S., TISZLAVICZ L., HEGYI P., MATKOVICS B., et al.: Oxidative stress in distant organs and the effects of allopurinol during experimental acute pancreatitis. International Journal of Pancreatology, 27 (3): 209-216, 2000.

13- TAKÁCS T., CZAKÓ L., MORSCHL É., LÁSZLÓ F., TISZLAVICZ L., RAKONCZAY J.R., et al.: The role of nitric oxide in edema formation in L-arginine-induced acute pancreatitis. Pancreas, 25 (3): 277-82, 2002.

14- RAKONCZAY Z., JÁRMAY K., KASZAKI J., MÁNDI Y., DUDA E., HEGYI P., et al.: NF- $\mathrm{KB}$ activation is detrimental in arginine-induced acute pancreatitis. Free Radical Biology and Medicine, 34 (6): 696-709, 2003.

15- TOOZE S.A., DOOLEY H.C., JEFFERIES H.B.J., et al.: Assessing mammalian autophagy. Methods in Molecular Biology, 1270: 155-65, 2015.

16- SURESHBABU A., RYTER S.W. and CHOI M.E.: Oxidative stress and autophagy: Crucial modulators of kidney injury. Redox Biology, 4: 208-14, 2015.

17- GUKOVSKAYA A.S., GUKOVSKY I., ALGÜL H. and HABTEZION A.: Autophagy, Inflammation, and Immune 
Dysfunction in the Pathogenesis of Pancreatitis. Gastroenterology, 153: 1212-26, 2017.

18- KARAKAHYA M., GÜL, M., IŞIK S., AYDIN C., YIGITCAN B., OTAN E., et al.: The Histopathologic Effects of 1-Carnitine in a Sodium Taurocholate-Induced Severe Pancreatitis Model. International Surgery, 101 (5): 241-8, 2016.

19- CALABRESE V., RAVAGNA A., COLOMBRITA C., SCAPAGNINI G., GUAGLIANO E., CALVANI M., et al.: Acetylcarnitine induces heme oxygenase in rat astrocytes and protects against oxidative stress: Involvement of the transcription factor Nrf2. Journal of Neuroscience Research, 79 (4): 509-21, 2005.

20- TAKÁCS T., HEGYI P., JÁRMAY K., CZAKÓ L., GÓG C., RAKONCZAY J.R.Z., et al.: Cholecystokinin fails to promote pancreatic regeneration in diabetic rats following the induction of experimental pancreatitis. Pharmacological research, 44 (5): 363-72, 2001.

21- YILDIRIM S., YILDIRIM A., DANE S., ALIYEV E., and YIGITOGLU R.: Dose-dependent protective effect of L-carnitine on oxidative stress in the livers of hyperthyroid rats. The Eurasian Journal of Medicine, 45 (1): 1, 2013.

22- BUÑAG R.D. and EFERAKEYA J.E.: Reduced cardiovascular responsiveness to hypothalamic stimulation during urethane and amobarbital anesthesia. Pharmacology, 10 (3): 143-51, 1973.

23- YARI A., ASADI M.H., BAHADORA H., DASHTNAVARD H., IMANI H. and NAGHII M.R.: Cadmium toxicity in spermatogenesis and protective effects of Lcarnitine in adult male rats. Biological trace element research, 137 (2): 216-25, 2010.

24- BUÑAG R.D. and EFERAKEYA J.E.: Reduced cardiovascular responsiveness to hypothalamic stimulation during urethane and amobarbital anesthesia. Pharmacology, 10 (3): 143-15, 1973.

25- ZOLADZ P.R., FLESHNER M. and DIAMOND D.M.: Differential effectiveness of tianeptine, clonidine and amitriptyline in blocking traumatic memory expression, anxiety and hypertension in an animal model of PT SD. Progress in Neuro-Psychopharmacology and Biological Psychiatry, 44: 1-16, 2013.

26- MELO C.M., CARVALHO K.M.M.B., De SOUSA NEVES J.C., MORAIS T.C., RAO V.S., et al.: $\alpha, \beta$-amyrin, a natural triterpenoid ameliorates L-arginine-induced acute pancreatitis in rats. World Journal of Gastroenterology, 16 (34): 4272, 2010.

27- TIETZE F.: Enzymic method for quantitative determination of nanogram amounts of total and oxidized glutathione: Applications to mammalian blood and other tissues. Analytical biochemistry, 27 (3): 502-22, 1969.

28- UCHIYAMA M. and MIHARA M.: Determination of malonaldehyde precursor in tissues by thiobarbituric acid test. Biochemistry, 86 (1): 271-8, 1978.

29- KIERNAN J.A.: Histological and histochemical methods: Theory and practice. ${ }^{3^{\text {re }}}$ ed. Arnold Publisher; London, New York \& New Delh, 111-62, 2001.

30- BANCROFT J. and COOK H.C.: Immunocytochemistry. In: Manual of histological techniques and their diagnostic applications. ${ }^{\text {rd }}$ ed. Churchill Livingstone; Edinburgh,
London, Madrid, Melbourne, New York and Tokyo, 263325, 2001.

31- SCHMIDT J. and RATTNER D.W., LEWANDROWSKI K., et al.: A better model of acute pancreatitis for evaluating therapy. Ann. Surgury, 215: 44, 1992.

32- CHAN Y.H.: Biostatistics 102: Quantitative data-parametric \& non-parametric tests. Blood pressure, 140 (24.08): 79100, 2003.

33- FROSSARD J.L., LESCUYER P. and PASTOR C.M.: Experimental evidence of obesity as a risk factor for severe acute pancreatitis. World Journal of Gastroenterology, 15 (42): 5260, 2009.

34- FORSMARK C.E. and TOSKES P.P.: Acute pancreatitis. Medical management. Critical care clinics, 11 (2): 295 309, 1995.

35- MATULL W.R., PEREIRA S.P. and O'DONOHUE J.W.: Biochemical markers of acute pancreatitis. Journal of Clinical Pathology, 59 (4): 340-4, 2006.

36- ARMSTRONG J.A., CASH N., SOARES P.M.G., SOUZA, M.H.L.P., SUTTON R. and CRIDDLE D.N.: Oxidative stress in acute pancreatitis: Lost in translation? Free Radical Research, 47 (11): 917-33, 2013.

37- YOUSEF M.I., OMAR S.A., EL-GUENDI M.I. and ABDELMEGID L.A.: Potential protective effects of quercetin and curcumin on paracetamol-induced histological changes, oxidative stress, impaired liver and kidney functions and haematotoxicity in rat. Food Chemical Toxicology, 48: 3246-61, 2010.

38- DEL RIO D., STEWART A.J. and PELLEGRINI N.: A review of recent studies on malondialdehyde as toxic molecule and biological marker of oxidative stress. Nutrition Metabolism Cardiovascular Disease, 15: 316-28, 2005.

39- HUGHES M.F.: Arsenic toxicity and potential mechanisms of action. Toxicology Letters, 133: 1-16.

40- GÜLÇIN I.: Antioxidant and antiradical activities of Lcarnitine, Life Science, 78: 803-11, 2002.

41- LYSIAK W., LILLY K., DILISA F., TOTH P.P. and BIEBER L.L.: Quantitation of the effect of L-carnitine on the levels of acid-soluble short-chain acyl-CoA and $\mathrm{CoASH}$ in rat heart and liver mitochondria. Journal of Biological Chemistry, 263 (3): 1151-6, 1988.

42- MINGORANCE C., RODRÍGUEZ-RODRÍGUEZ R., JUSTO M.L., De SOTOMAYOR M.Á. and HERRERA M.D.: Critical update for the clinical use of L-carnitine analogs in cardiometabolic disorders. Vascular health and risk management, 7: 169, 2011.

43- BOTHAM K.M. and MAYES P.A.: Lipids of physiologic significance. Harper's Illustrated Biochemistry, Murray, RK, Granner, DK, Mayes, PA and Rodwell, VW (eds.). TheMcGraw-Hill Companies, Inc. USA, 121-31, 2006.

44- GUKOVSKY I., LI N., TODORIC J., GUKOVSKAYA A. and KARIN M.: Inflammation, autophagy, and obesity: Common features in the pathogenesis of pancreatitis and pancreatic cancer. Gastroenterology, 144 (6): 1199-209, 2013.

45- ARENINOVA O.A., HERMANN K., FRENCH S.W., O'KONSKI M.S., PANDOL S.J., WEBSTER P. and GU- 
KOVSKAYA A.S.: Impaired autophagic flux mediates acinar cell vacuole formation and trypsinogen activation in rodent models of acute pancreatitis. The Journal of Clinical Investigation, 119 (11): 3340-55, 2009.

46- GUKOVSKAYA A.S. and GUKOVSKY I.: Autophagy and pancreatitis. Am. J. Physiol. Gastrointest. Liver Physiol., 303: G993-G1003, 2012.

47- MOLEJON M.I., ROPOLO A., RE A.L., BOGGIO V. and VACCARO M.I.: The VMP1-Beclin 1 interaction regulates autophagy induction. Scientific Reports, 3: 1055, 2013.

48- CALABRESE V., RAVAGNA A., COLOMBRITA C., SCAPAGNINI G., GUAGLIANO E., CALVANI M., et al.: Acetylcarnitine induces heme oxygenase in rat astrocytes and protects against oxidative stress: Involvement of the transcription factor Nrf2. Journal of Neuroscience Research, 79 (4): 509-21, 2005.

49- IOVANNA J.L.: Cellular Stress in Acute Pancreatitis. In
Pancreatology (pp. 9-24). Springer, Berlin, Heidelberg, 2009.

50- KAYA I., CITIL M., SOZMEN M., KARAPEHLIVAN M. and CIGSAR G.: Investigation of protective effect of L-carnitine on L-asparaginase-induced acute pancreatic injury in male Balb/c mice. Digestive Diseases and Sciences, 60 (5): 1290-6, 2015.

51- ZHAO M., JIANG Q., WANG W., GENG M., WANG M., HAN Y. and WANG C.: The Roles of Reactive Oxygen Species and Nitric Oxide in Perfluorooctanoic AcidInduced Developmental Cardiotoxicity and 1-Carnitine Mediated Protection. International Journal of Molecular Sciences, 18 (6): 1229, 2017.

52- SIMSEK I., REFIK M., YASAR M., OZYURT M., SAGLAMKAYA U., DEVECI S. and KOCABALKAN F.: Inhibition of inducible nitric oxide synthase reduces bacterial translocation in a rat model of acute pancreatitis. Pancreas, 23 (3): 296-301, 2001.

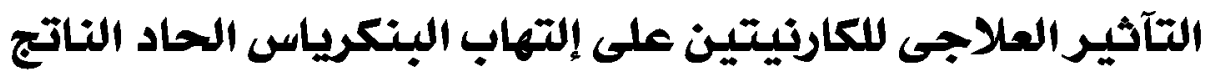

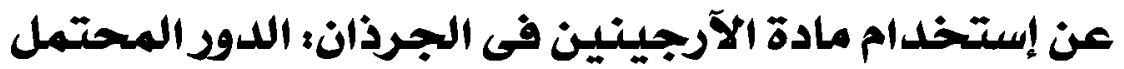

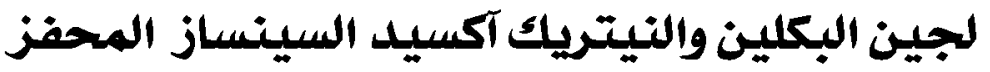

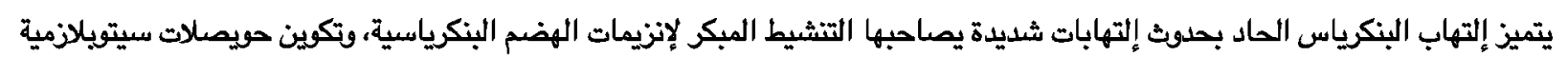

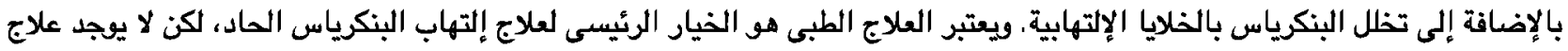
محدد فعال لعلاجه.

هدف الدراسة: دراسة التآثير العلاجى لمادة الكارنيتين بجرعات مختلفة على إلتهاب البنكرياس الحاد الناتج عن إستخدام مادة الآرجينين في الجرذان البالغة.

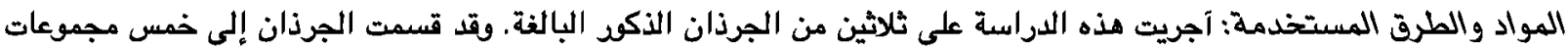

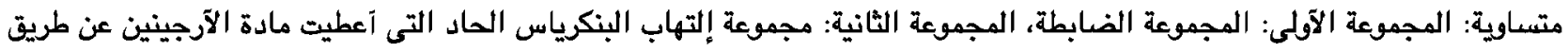

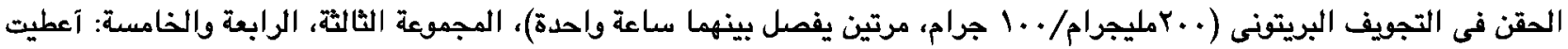

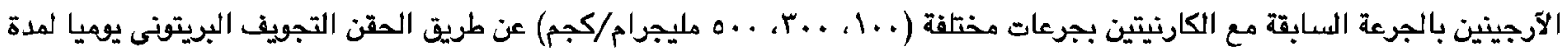
إسبوع، وقد تم تصديد مدى تآثر البنكرياس بطرق الارنين فارماكوعلوجية وكيميائية ونسيجية.

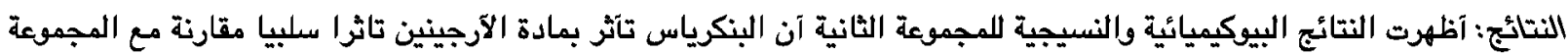

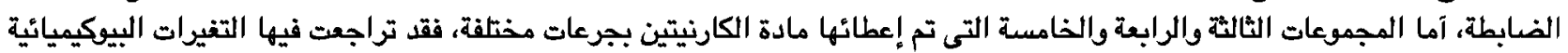

$$
\text { والنسيجية خصوصا مع جرعة (. .ممليجرام/كجم). }
$$

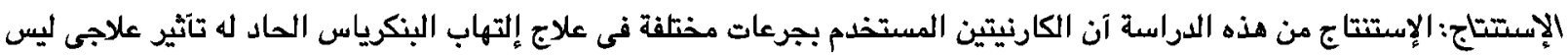

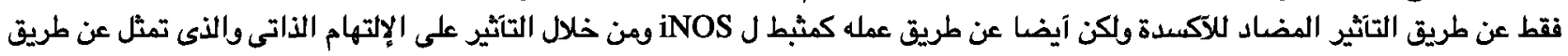

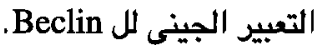

